УДК 342.25

DOI https:/ / doi.org/10.32837 / yuv.v0i6.2030

\title{
B. Нестор,
}

кандидат юридичних наук

\section{МІСЬКЕ САМОВРЯДУВАННЯ У ВЕЛИКОБРИТАНІЇ ЗА ЧАСІВ ДЕВОЛЮЦІЇ ВЛАДИ}

\begin{abstract}
Постановка проблеми та i актуальність. Британські муніципальні реформи завжди викликали неабиякий інтерес у науковців. Тим більше, коли ці реформи були викликані не необхідністю підвищити ефективність муніципальних органів, а іншими факторами.

Так, станом на кінець ХХ століття муніципальне управління, у т.ч. міське самоврядування у Сполученому Королівстві, не викликало значних зауважень із точки зору його ефективності та дієвості.
\end{abstract}

Акт про місцеве управління 1972 року містив положення, відповідно до яких відбулась комплексна муніципальна реформа на території таких історичних частин країни, як Англія та Уельс (для Шотландіï Парламентом Сполученого Королівства було прийнято окремий Акт $з$ аналогічною назвою так само, як і для Північної Ірландії, це відбулося також у 1972 році):

- була оновлена система адміністративно-територіального поділу;

- місцеве самоврядування стало дволанковим у кожній 3 історичних частин Сполученого Королівства (по теперішній час у столиці та у неметрополітенських графствах воно залишається дволанковим);

- була уніфікована не тільки кількість ланок органів місцевого самоврядування, але й матеріально-фінансові основи їхньої діяльності, адміністративний контроль за їх функціонуванням (він майже не застосовується у Сполученому Королівстві, однак $€$ випадки, коли його здійснення є необхідним); $\begin{array}{llr}\text { - була } & \text { переглянута } & \text { компетенція } \\ \text { органів } & \text { місцевого } & \text { самовряду- }\end{array}$ вання - вони отримали від держави повноваження у сфері охорони здоров'я та санітаріі, а також водопостачання. Ті повноваження, які традиційно належали органам місцевого самоврядування, були ретельно систематизовані, після чого їх було поділено між муніципальними органами кожної з двох ланок (районами та графствами). Найбільш важливі для жителів населених пунктів, у т.ч. міських населених пунктів, повноваження було надано як районам, так і графствам.

У контексті дослідження міського самоврядування варто зазначити, що більша частина сіті отримала статус районів (дістриктів) для здійснення муніципального управління. Таким чином, під час розробки організації міського самоврядування особливості міських населених пунктів не враховувалися, адже райони охоплювали не тільки ці населені пункти, але й сільські. Іншими словами, управління на містах було спрощено та уніфіковано.

Аналіз останніх досліджень i публікацій. Питання міського самоврядування у Сполученому Королівстві Великобританії і Північної Ірландії в порівняльному контексті з Україною поки що не аналізувалися. Що ж до питань компаративного дослідження місцевого самоврядування в цих країнах загалом, то воно розроблялось лише професором Н.В. Мішиною [1-3]. Однак вона не публікувала праці, присвячені історії самоврядування в цій країні, у т.ч. про британську деволюцію. 


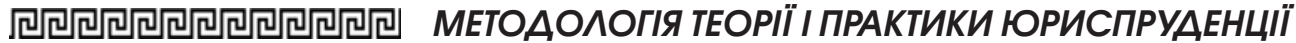

Метою статті $€$ аналіз історичного досвіду міського самоврядування у Сполученому Королівстві в контексті британської деволюції.

Виклад основного матеріалу. Деволюція публічної влади відбувалась у Сполученому Королівстві наприкінці XX - на початку XXI століття. Ця реформа відбувалась цілком у дусі загальноєвропейських тенденцій - O.M. Богатирьова зауважила, що «такі країни, як Бельгія, Іспанія, Великобританія і Італія, почали процес децентралізації для того, щоб послабити територіальну або етнічну напруженість і зберегти єдність країни [4, с. 6].

Конкретно в британському контексті, як справедливо узагальнила C.I. Коданєва, «друга половина XX ст. для Сполученого Королівства Великої Британії та Північної Ірландії була позначена зростанням націоналістичних тенденцій на окраїнах, в трьох частинах країни: в Уельсі, Шотландії та Північної Ірландії. Радикали націоналістичних рухів у цих регіонах закликали до відділення від Англії 3 подальшим утворенням власних держав (Північна Ірландія бажає приєднатися до Ірландської Республіки)» [5, с. 5]. С.О. Шеїн у своєму дисертаційному дослідженні на здобуття наукового ступеня кандидата політичних наук на тему «Політична стратегія сучасних британських консерваторів в процесі політико-інституційної трансформації Сполученого Королівства» зазначив, що в умовах чергової політичної кризи «необхідною була нова модель взаємовідносин між центром і етнорегіонами для зміцнення цілісності Сполученого Королівства. У контексті особливостей Вестмінстерської моделі демократії і традицій політичного реформування британський політичний клас знайшов відповідь в деволюції» [6, с. 137].

Отже, «створення власних регіональних органів управління в двох історичних частинах країни і відновлення - в третій, відкриває новий і важливий розділ у британській конституційній історії. Поява Національної Асамблеї Уельсу, Парламенту Шотландії і Асамблеї Північної Ірландії стало конституційною революцією, незрівнянною, мабуть, ні 3 якими іншими змінами, що раніше мали місце в Сполученому Королівстві» [7, с. 1]. Ці зміни є важливими в контексті дослідження міського самоврядування тому, що до повноважень представницьких органів Шотландії, Уельсу та Північної Ірландії належить вирішення питань організації місцевого самоврядування загалом та міського самоврядування зокрема. Таким чином, Парламент Сполученого Королівства здійснює нормативно-правову регламентацію лише місцевого, у т.ч. міського самоврядування в Англіі.

Хронологічно першою історичною частиною, приєднаною до Англіі, став Уельс. Як зазначають дослідники, «Уельс (вал. Суmru) - історично самобутній регіон Сполученого Королівства Великобританіі і Північної Iрландіï. Він першим, ще наприкінці XIV ст. з'єднався з Англією, тому більш глибоко інтегрований 3 нею, ніж Шотландія і Північна Ірландія» [8, с. 156].

Внаслідок здійснення деволюціі в Уельсі почав функціонувати такий представницький орган, як Асамблея, а також інші органи публічної влади, яких не було за попередніх часів. Резюмуючи наслідки аналізованої реформи для Уельсу, дослідники зазначають, що «процес деволюції в Уельсі привів до формування ефективних органів законодавчої та виконавчої влади, які взяли на себе політичну відповідальність за розвиток регіонів. Деволюція в Уельсі також сприяла збереженню валлійської мови, що було однією з першочергових задач додеволюційного періоду» [9, с. 98].

Хронологічно наступною (після Уельсу) до Англії була приєднана Шотландія; «після укладення англо-шотландської парламентської 
уніі 1707 р. більша частина шотландських легіслатур, включаючи парламент, була переміщена з Единбурга в Лондон, що стало основою поширення націоналістичних настроїв» [10, с. 79]. У Шотландії було поновлено функціонування представницького органу, який припинив своє існування внаслідок уніі - Парламенту Шотландії; працює і система органів виконавчої влади.

Аналогічні зміни відбулися у Північній Ірландії - там 3'явився колегіальний представницький орган Асамблея Північної Ірландії, а також низка органів, на які покладено виконання актів Асамблеї.

Вище було зазначено, що до компетенції Асамблеї Уельсу, Парламенту Шотландії та Асамблеї Північної Ірландії було зараховано регламентацію місцевого самоврядування на відповідних територіях, вони отримали такі повноваження на початку XXI століття та активно застосовують надані можливості. Внаслідок цього місцеве самоврядування в чотирьох історичних частинах Сполученого Королівства вже має доволі істотні відмінності. Ймовірно, з часом ці відмінності ставатимуть більш істотними.

Правове регулювання місцевого самоврядування - це одне з небагатьох повноважень, яке було передано кожному з трьох вищезгаданих новоутворених представницьких органів. Загалом ці «три нових законодавчих органи мають неоднакові повноваження і сукупність функцій.

У Шотландіі і Північній Ірландії використовується принцип координаціï. Так, новий Парламент Шотландії має право приймати акти законодавства з будь-якого питання, яке спеціально не залишено у відомі «Вестмінстерського парламенту».

В Уельсі, навпаки, використовується принцип кооперації: Національна асамблея розділяє функції 3 центральним урядом. Асамблея може видавати тільки акти вторинного законодавства - правила та інструкції, що розвивають і конкретизують первинне законодавство, яке видається «Вестмінстерським парламентом» $[11$, с. 71$]$.

Також варто наголосити на тому, що «Вестмінстерський парламент» - Парламент Сполученого Королівства - має повноваження щодо регламентації муніципального управління лише в Англії. Як наголошують дослідники, «в результаті здійснення політики деволюції 3 кінця 90-х pp. ХX ст. Шотландія може вибирати власний Парламент, Уельс - Асамблею, навіть Північна Ірландія має виборний Стормонт, а Англія не має нічого. Але ж значна частина населення Британських островів мешкає саме в Англії, тобто $4 / 5$ всього населення Сполученого Королівства. I в рамках деволюційної політики саме Англія виявилася обмеженою у своїх інтересах, саме іï роль лідера слабшає в четвірці «внутрішніх» націй. Таким чином, «англійське питання» зводиться до наступного: після прийняття Акта про деволюцію Шотландія і Уельс з 1997 р. не тільки мають власні представницькі органи, але їх повноваження постійно розширюються, але тоді як управляти Англією?» [12, с. 150]. Є.В. Ноздрачьов наголошує на тому, що процес деволюції поки що не завершено, та що «важливою проблемою, від способу вирішення якої будуть залежати перспективи розвитку і зміст концепції деволюції в майбутньому, є проблема адміністративно-територіального статусу Англї̈ [13, с. 57].

Варто навести ще один цікавий факт, про який у контексті дослідження місцевого самоврядування у Сполученому Королівстві на рівні міських населених пунктів пише Т.М. Гелла: «Більшість жителів Шотландії і Північної Ірландії проголосували за те, щоб залишитися в ЄС, Англія і Уельс - в основному за вихід. Показово, що за виключення трьох промислових центрів - Бірмінгема, Ноттінгема і Шеффілда, насе- 


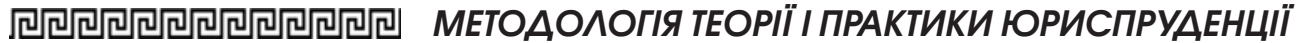

лення найбільших англійських міст, в тому числі і Лондона, висловилося за збереження членства країни в ЄС. Тепер досить активно обговорюється питання, наскільки влада цих міст будуть залучатися до переговорного процесу про розподіл повноважень між центральною та регіональною владою» [12, с. 153]. Це є ще одним вагомим фактом щодо того, як саме міські населені пункти набувають дедалі більшої ваги не тільки в економічному, культурному тощо, але й у політичному житті.

Висновки. Отже, у Сполученому Королівстві існують чотири системи місцевого самоврядування - по одній на кожну історичну частину країни. Відповідно, існують чотири підходи до міського самоврядування. Загальна, «спільна» для усіх чотирьох історичних частин країни система місцевого самоврядування на сучасному етапі відсутня.

Перспективи подальших досліджень у цьому напрямі вбачаються в аналізі попереднього та наступних історичних періодів у розвитку міського самоврядування у Сполученому Королівстві Великобританіі і Північної Ірландії.

Метою статті є проаналізувати історичний досвід міського самоврядування у Сполученому Королівстві в контексті британської муніциипальної революичї.

Акт про місцеве управління 1972 року містив положення, відповідно до яких відбулась комплексна муніципальна реформа на територіï таких історичних частин країни, як Англія та Уельс (Әля Шотландї Парламентом Сполученого Королівства було прийнято окремий Акт з аналогічною назвою так само, як $і$ для Північної Ірландї, це відбулося також у 1972 році): а) була оновлена система адміністративно-територіального поділу; б) місиеве самоврядування стало дволанковим у кожної $з$ історичних частин Сполученого Королівства (nо теперішній час у столиці та неметрополітенських графствах воно залишається дволанковим); в) була уніфікована не тільки кількість ланок органів місцевого самоврядування, але ŭ матеріально-фінансові основи їхьої діяльності, адміністративний контроль за їх функціонуванням (він майже не застосовується у Сполученому Королівстві, однак $\epsilon$ випадки, коли його здійснення $\epsilon$ необхідним) тошо.

У контексті дослідження міського самоврядування варто зазначиmu, що більша частина сіті отримала статус районів (дістриктів) для здійснення муніципального управління. Таким чином, під час розробки організації міського самоврядування особливості міських населених пунктів не враховувалися, адже райони охоплювали не тільки изі населені пункти, але й сільські. Іншими словами, управління на містах було спрощено та уніфіковано.

Зміни XX - XXI століть є важливими в контексті дослідження міського самоврядування тому, що до повноважень представницьких органів Шотландї, Уельсу та Північної Ірландї належить вирішення питань організації місцевого самоврядування загалом та міського самоврядування зокрема. Таким чином, Парламент Сполученого Королівства здійснюе нормативно-правову регламентацію лише місцевого, у т.ч. міського самоврядування в Англї.

Резюмовано, шо у Сполученому Королівстві існують чотири системи місцевого самоврядування - по одній на кожну історичну частину країни. Відповідно, є чотири підходи до міського самоврядування. Загальна, «спільна» Әля усіх чотирьох історичних частин країни система місцевого самоврядування на сучасному етапі відсутня. 
Ключові слова: міське самоврядування, місцеве самоврядування, місто, міська територіальна громада, територіальна громада, публічна влада.

Nestor V. City government in the United Kingdom during the devolution

The aim of the article is to analyze the historical experience of urban selfgovernment in the United Kingdom in the context of the British municipal revolution.

The Local Government Act 1972 contained provisions for a comprehensive municipal reform in historical parts of the country such as England and Wales (for Scotland, the United Kingdom Parliament adopted a separate Act with the same name, as for Northern Ireland, it is also took place in 1972): a) the system of administrative-territorial division was updated; b) local selfgovernment has become two-tiered in each of the historical parts of the United Kingdom (to this day in the capital and in non-metropolitan counties it remains two-tiered); c) not only the number of local selfgovernment bodies was unified, but also the material and financial bases of their activity, administrative control over their functioning (it is almost not applied in the United Kingdom, but there are cases when its implementation is necessary), etc.

In the context of the study of municipal self-government, it should be noted that most of the network has received the status of districts (districts) for the implementation of municipal government. Thus, when developing the organization of urban self-government, the peculiarities of urban settlements were not taken into account, because the districts covered not only these settlements, but also rural ones. In other words, urban governance has been simplified and unified.

The changes of the $X X-$ $X X I$ centuries are important in the context of the study of urban selfgovernment because the powers of the representative bodies of Scotland, Wales and Northern Ireland include the organization of local selfgovernment in general and urban self-government in particular. Thus, the Parliament of the United Kingdom carries out legal regulations only local, including city self-government in England.

In summary, there are four local government systems in the United Kingdom, one for each historical part of the country. Accordingly, there are four approaches to urban self-government. There is no general, "common" system of local self-government for all four historical parts of the country at the present stage.

Key words: city government, local government, city, city territorial community, territorial community, public authority.

\section{Література}

1. Мішина H.B. Територіальні громади та об'єднані територіальні громади в Україні. Наукові праці НУ ОЮА. 2019. T. 24. C. $75-80$.

2. Мішина Н.В. Актуальні проблеми викладання муніципального права в Україні. Наукові праці НУ ОЮА. 2016. T. 15. C. 161-167.

3. Мішина Н.В. Деякі особливості муніципального управління в Лондоні. Актуальні проблеми держави і права: Збірник наук. пращь. 2004. Bun. 22. C. 229-233.

4. Богатырева О.Н. Процессы децентрализациии в европейских странах. Электронное приложение к Российскому юридическому журналу. 2018. № 2. С. 5-20.

5. Коданева С.И. Британская конституциионая реформа: региональный аспект. Аналитический обзор / РАН. ИНИОН. Центрсоциал. науч.-информ. исслед. Отд. правоведения. Москва, 2005. 112 с.

6. Шеин С.A. Политическая стратегия современных британских консерваторов в процессе политико-институщиональной трансформации Соединенного Королевства: дис. ... канд. полит. наук. Пермь, 2016. 234 с.

7. Коданева С.И. Политическая регионализация в Соединенном Королевстве 


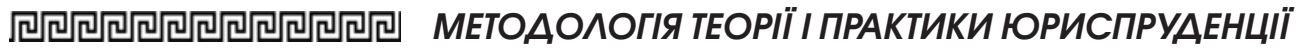

Великобритании и Северной Ирландии: конституционная реформа : автореф. дис. ... канд. юрид. наук. Москва, 2003. 22 с.

8. Пронкин С.В. Уэльс: долгий путь к деволюиии. Вестник Московского универcuтета. Серия 21. Управление (государство и общество). 2016. № 4. С. 155-168.

9. Каракчиев П.О. Региональная деволюиия в Уэльсе. Современная Европа. 2007. № 3. С. 85-98.

10. Апрыщенко В.Ю. Национализм и институциональная идентичность: местное управление в Шотландии в XVIII - I половине XIX века. Нзвестия высших учебных заведений. СевероКавказский регион. Общественные науки. 2008. № 5. С. 78-82.
11. Саламова П.А. Специфика реформы местного самоуправления Великобритании в контексте региональной политики конца ХX - начала XXI века. Вестник Российского университета дружбы народов. Серия: Юридические науки. 2006. № 3. С. 69-72.

12. Гелла Т.Н. "Английский вопрос» в политике деволюции современной Великобритании. Среднерусский вестник общественных наук. 2017. Т. 12. № 5. C. 148-155.

13. Ноздрачёв Е.В. Кониепиия деволюиии в новейщей истории Великобритании. Ученые записки Орловского государственного университета. Серия: Гуманитарные и социальные науки. 2015. № 5. C. 55-58. 